\title{
Alcohol Production from Cheese Whey Permeate Using Genetically Modified Flocculent Yeast Cells
}

\author{
Lucília Domingues, Nelson Lima, José A. Teixeira \\ Centro de Engenharia Biológica-IBQF, Universidade do Minho, Campus \\ de Gualtar, 4710-057 Braga, Portugal; telephone: +351-253604400; \\ fax: +351-253-678986; e-mail: jateixeira@deb.uminho.pt
}

Received 23 March 2000; accepted 28 September 2000

\begin{abstract}
Alcoholic fermentation of cheese whey permeate was investigated using a recombinant flocculating Saccharomyces cerevisiae, expressing the LAC4 (coding for $\beta$-galactosidase) and $L A C 12$ (coding for lactose permease) genes of Kluyveromyces marxianus enabling for lactose metabolization. Data on yeast fermentation and growth on cheese whey permeate from a Portuguese dairy industry is presented. For cheese whey permeate having a lactose concentration of $50 \mathrm{gL}^{-1}$, total lactose consumption was observed with a conversion yield of ethanol close to the expected theoretical value. Using a continuously operating 5.5-L bioreactor, ethanol productivity near $10 \mathrm{~g} \mathrm{~L}^{-1} \mathrm{~h}^{-1}$ (corresponding to $0.45 \mathrm{~h}^{-1}$ dilution rate) was obtained, which raises new perspectives for the economic feasibility of whey alcoholic fermentation. The use of 2-times concentrated cheese whey permeate, corresponding to $100 \mathrm{gL}^{-1}$ of lactose concentration, was also considered allowing for obtaining a fermentation product with 5\% (w/v) alcohol. (c) 2001 John Wiley \& Sons, Inc. Biotechnol Bioeng 72: 507-514, 2001
\end{abstract}

Keywords: whey permeate fermentation; recombinant yeast; ethanol production; continuous culture; flocculation

\section{INTRODUCTION}

Cheese whey is a by-product of dairy industries, which presents rather high pollutant characteristics and is produced in high amounts. Whey disposal has been under consideration for several years. The first option considered was drying it and using it as an additive in food or as feed. In this way, the discharge problem was solved but no value was added. As cheese whey has a high content of protein $(1 \%$ $\mathrm{w} / \mathrm{v})$ and lactose $(5 \% \mathrm{w} / \mathrm{v})$, it is appropriate to consider this material as a source of added value compounds and not just as an effluent. The use of whey as a raw material for production of a variety of products (ethanol, biomass, acid lactic, etc.) has been considered by several authors (Compagno et al., 1993; Feijoo et al., 1999; Mann, 1980; Maullu et al., 1999; Mehaia and Cheryan, 1986; Michel et al., 1987;

Correspondence to: José A. Teixeira

Contract grant sponsor: Instituto de Biotecnologia e Química Fina (IBQF), Portugal; Fundação para a Ciência e Tecnologia, Portugal

Contract grant number: PRAXIS XXI/BD/11306/97
Prenosil et al., 1987; Rech et al., 1999; Sonawat et al., 1981; Tahoun et al., 1987). Nowadays, after whey powder and demineralized whey powder, the third major products obtained from cheese whey are whey protein concentrates (WPC) (Horton, 1996). The nutritional and medical characteristics of WPC are generally accepted and the market for WPC is increasing not only for the concentrate as a whole, but also for individual proteins (as $\beta$-lactoglobulin or $\alpha$-lactalbumin) or even peptides resulting from protein hydrolysis. When producing WPC, typically by ultrafiltration, a lactose-rich fraction, the cheese whey permeate, is obtained. This can be used directly as feed, to produce lactose, or as substrate for fermentation such as alcoholic fermentation (Moulin et al., 1980; Moulin and Galzy, 1984). The lactose, the largest component in whey, is the most problematic to dispose of economically (Horton, 1996)

The metabolization of lactose by recombinant $S$. cerevisiae has been addressed by several authors (Domingues et al., 1999a; Farahnak et al., 1986; Kumar et al., 1992; Porro et al., 1992; Rubio-Teixeira et al., 1998; Sreekrishna and Dickson, 1985; Tretiak et al., 1998) but only some have addressed lactose fermentation (Domingues et al., 1999b; Compagno et al., 1995; Ramakrishnan and Hartley, 1993). Microorganisms other than S. cerevisiae have been considered for lactose fermentation (Guimaraes et al., 1992; Teixeira et al., 1990) and ethanol is currently produced from whey in countries such as New Zealand (Mawson, 1987) or from deproteinized cheese whey in Ireland (Barry, 1982; Lyons and Cunningham, 1980;) and in the United States (Walker, 1982). Efforts have been made to improve the productivity for cheese whey permeate alcoholic fermentation. For an optimized batch process with a Kluyveromyces fragilis strain adapted to high lactose concentrations, using as substrate demineralized concentrated cheese whey permeate (CCWP) with $24 \%$ lactose content, a productivity of $3.2 \mathrm{~g} \mathrm{~L}^{-1} \mathrm{~h}^{-1}$ was obtained corresponding to a $108.8 \mathrm{~g} \mathrm{~L}^{-1}$ ethanol concentration (Gawel and Kosikowski, 1978). For continuous processes, Jassens et al. (1984) reported an ethanol productivity of $7.1 \mathrm{~g} \mathrm{~L}^{-1} \mathrm{~h}^{-1}$ for $K$. fragilis operating with cell recycling at $D=0.15 \mathrm{~h}^{-1}$ and for CCWP with 100 $\mathrm{g} \mathrm{L}^{-1}$ lactose. For immobilized continuous processes ethanol productivity values such as $1.1 \mathrm{~g} \mathrm{~L}^{-1} \mathrm{~h}^{-1}$ for im- 
mobilized $K$. fragilis and $4.5 \mathrm{~g} \mathrm{~L}^{-1} \mathrm{~h}^{-1}$ for S. cerevisiae coimmobilized with $\beta$-galactosidase have also been reported (Hahn-Hägerdal, 1985). Terrel et al. (1984) reported an ethanol productivity of $13.6 \mathrm{~g} \mathrm{~L}^{-1} \mathrm{~h}^{-1}$ for CCWP with $150 \mathrm{gL}^{-1}$ lactose concentration operating at continuous operation with cell recycling at $D=0.2 \mathrm{~h}^{-1}$. However, this was attained with an $S$. cerevisiae strain (mutant strain showing no catabolite repression) and thus the CCWP had to be hydrolyzed to glucose and galactose prior to use. Nevertheless, it is our belief that by using high cell density systems with flocculent yeast cells the productivity of alcoholic fermentation of cheese whey permeate can be improved. The use of flocculent cells with an adequate bioreactor design allows for high biomass concentration inside the bioreactor, making possible continuous operation at higher dilution rates and thus higher ethanol productivity. In addition, the downstream processing is greatly facilitated due to cell sedimentation characteristics. Moreover, the main drawback associated with continuous operation, the contamination problem, is not relevant when working with this system at sufficiently high-dilution rates (Domingues et al., 2000).

In this work, a recombinant and flocculent Saccharomyces cerevisiae was used to continuously ferment cheese whey permeate in a high cell density system allowing for high ethanol productivity.

\section{MATERIAL AND METHODS}

\section{Microorganism}

A recombinant Saccharomyces cerevisiae NCYC869-A3/ $\mathrm{T} 1$ flocculent strain expressing the LAC4 (coding for $\beta$-galactosidase) and LAC12 (coding for lactose permease) of Kluyveromyces lactis was used. The construction of the recombinant strain has previously been described (Domingues et al., 1999a).

\section{Culture Media and Batch Cultures}

The recombinant yeast was maintained at $4^{\circ} \mathrm{C}$ on slants or at $-80^{\circ} \mathrm{C}$ in permanent culture of YNB selective medium having the following composition: $6.7 \mathrm{gL}^{-1}$ yeast nitrogen base (w/o amino acids), $20 \mathrm{gL}^{-1}$ lactose. SSLactose medium, of the following composition: $\mathrm{KH}_{2} \mathrm{PO}_{4} 5 \mathrm{gL}^{-1}$; $\left(\mathrm{NH}_{4}\right)_{2} \mathrm{SO}_{4} 2 \mathrm{gL}^{-1} ; \mathrm{MgSO}_{4} .7 \mathrm{H}_{2} \mathrm{O} 0.4 \mathrm{gL}^{-1}$; yeast extract $1.0 \mathrm{gL}^{-1}$; lactose $50 \mathrm{gL}^{-1}$ or $100 \mathrm{gL}^{-1}$ was used. Sweet cheese whey permeate (CWP) obtained by ultrafiltration from a Portuguese dairy with a lactose concentration of approximately $50 \mathrm{gL}^{-1}$ was initially assayed. The CWP was further concentrated by nanofiltration as the retentate and named concentrated cheese whey permeate (CCWP). The CCWP with approximately $100 \mathrm{gL}^{-1}$ lactose was also tested. The feed lactose concentration for the experiments done with CWP and CCWP was always measured. Yeast cultures were carried out at $30^{\circ} \mathrm{C}$ by rotary shaker with 150 rpm agitation, in $100 \mathrm{~mL}$ of culture medium in $250-\mathrm{mL}$ Erlenmeyer flasks. Alternatively, a 2-L bioreactor (Braun, Biostat ${ }^{\circledR}$ M) fitted with agitation and aeration control, temperature measurement and control, $\mathrm{pH}$ measurement and control was used. The temperature was maintained at $30^{\circ} \mathrm{C}$, the $\mathrm{pH}$ at 4.0 by automatic addition of an ammonia solution, agitation speed was set at $150 \mathrm{rpm}$ and the bioreactor was aerated with filtered air at a flow rate of $0.1 \mathrm{vvm}$. The fermentor vessel and tubing were autoclaved for $20 \mathrm{~min}$ at $121^{\circ} \mathrm{C}$.

\section{Continuous-Culture Experiments}

An airlift bioreactor of the concentric draft tube made of Perspex (Fig. 1) with a working volume of $5.5 \mathrm{~L}$ was used (Domingues et al., 1999b). The regulation system allows for: temperature control at $30 \pm 1{ }^{\circ} \mathrm{C}$; foam-level control by addition of antifoam (Sigma A-5551); and $\mathrm{pH}$ control by automatic addition of ammonia, being the set-point fixed at $\mathrm{pH} 4.0 \pm 0.1$. The system was aerated with filtered air at a flow rate of 0.0800 to $1.0000 \pm 0.0002 \mathrm{vvm}$. Flow rate was controlled using a Hastings mass-flow controller. It is worth noting that an increase in the air-flow rate was needed when increasing dilution rate to prevent the bioreactor from stalling. Dilution rate was varied during the experiments in the range 0.1 to $0.55 \mathrm{~h}^{-1}$.

For start-up of continuous culture, cells were grown in a 2-L Erlenmeyer flask filled with $1 \mathrm{~L}$ of culture medium, for $24 \mathrm{~h}$. The cell suspension was then aseptically transferred to the bioreactor, which was kept in batch operation for $24 \mathrm{~h}$ before switching on the feeding. Once pseudo-stationary

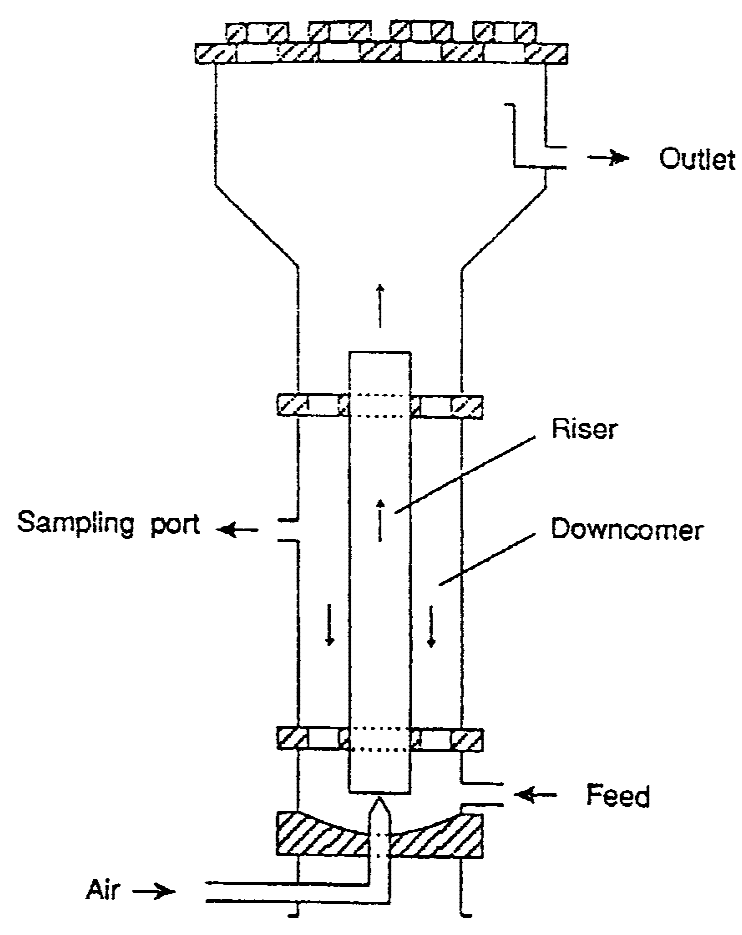

Figure 1. Schematic representation of the airlift bioreactor. 
state with semisynthetic medium was attained, the bioreactor was fed with sweet cheese whey permeate. A pseudostationary state is reached whenever lactose consumption and ethanol production have reached constant values. For the concentrated whey permeate the start-up of the continuous operation was made after a $24-\mathrm{h}$ batch culture in the bioreactor with concentrated cheese whey permeate.

\section{Analysis}

The cell concentration, i.e., biomass concentration, was estimated by the dry weight method. The dry weight cell concentration was determined by filtering the sample through $0.2-\mu \mathrm{m}$ filter paper and then dried at $105^{\circ} \mathrm{C}$ for 24 h. The lactose concentration was determined by the dinitrosalicylic acid method (Miller, 1959). Ethanol concentration was measured by an HPLC method (Poyspher® $\mathrm{CH}$ CA column, Merck). The solvent used was $0.1 \mathrm{~N} \mathrm{H}_{2} \mathrm{SO}_{4}$, at a

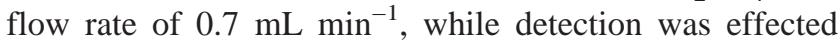
with a refractive-index detector. Temperature was maintained at $60^{\circ} \mathrm{C}$. Cell viability was estimated by the vital methylene blue staining method and direct cell counting in a Neubauer chamber.

\section{Screening for Contaminations Assay}

As cheese whey permeate was not autoclaved before being fed into the bioreactor, screening for contaminants was performed. This was done by sample spreading on lysine plates (Oxoid CM191). Lysine medium is a synthetic medium for the isolation and enumeration of wild yeasts encountered in brewing. On this medium, $S$. cerevisiae growth is suppressed because no normal $S$. cerevisiae or $S$. carlbergensis strains utilize lysine while many other types of yeast, including wild yeasts, do so. When using concentrated whey permeate the contamination assay was not done. Instead the concentrated whey permeate was acidified during its preparation, pasteurized at $60^{\circ} \mathrm{C}$ for $30 \mathrm{~min}$, and stored at $4^{\circ} \mathrm{C}$ until use.

\section{Flocculation Assay}

The flocculation assay was done as previously described (Domingues et al., 1999b). Cells were washed twice with 15 $\mathrm{gL}^{-1} \mathrm{NaCl}, \mathrm{pH} 3.0$, solution. A 24-mL volume of cell suspension was placed on a $25-\mathrm{mL}$ graduated cylinder. Then, 1 $\mathrm{mL}$ of a $100 \mathrm{~m} M \mathrm{CaCl}_{2}, \mathrm{pH} 3.0$, solution was added and the solution immediately mixed by inversion 18 times. Samples of $200 \mu \mathrm{L}$ were taken at the $20-\mathrm{mL}$ level at different times. To ensure floc dispersion, samples were treated with $\mathrm{NaCl}$ solution before OD reading at $620 \mathrm{~nm}$ (Soares et al., 1992). The normalized cell concentration defined as the ratio between actual and initial concentration was plotted against sedimentation time. A sedimentation profile was then obtained.

\section{Effluent Characterization}

The chemical oxygen demand (COD), biochemical oxygen demand $\left(\mathrm{BOD}_{5}\right)$, total suspended solids (TSS), and total nitrogen were analyzed according to standard methods (Clesceri et al., 1989).

\section{Cations Measurement}

The cations $\left(\mathrm{Na}^{+}, \mathrm{K}^{+}\right)$concentration was measured by atomic absorption spectrometry (Clesceri et al., 1989).

\section{RESULTS AND DISCUSSION}

Figure 2 shows the time course of cell, lactose, and ethanol concentrations, using SSmedium or cheese whey permeate (CWP) as substrate, in shake-flask cultures of the recombinant strain. As can be observed from Figure 2, the fermentation time is similar for both culture media, although a
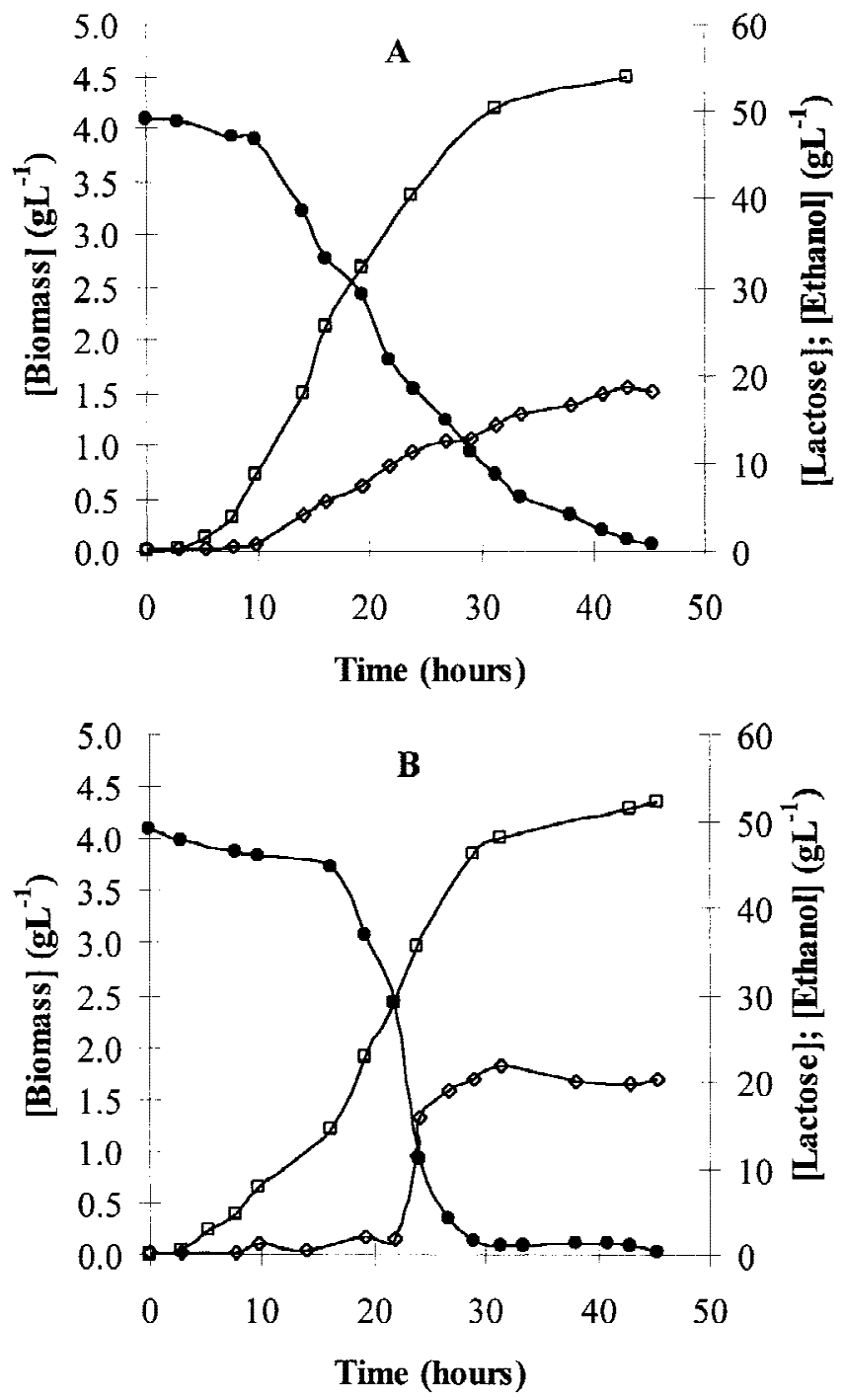

Figure 2. Cell $(\square)$, lactose $(\bullet)$ and ethanol $(\diamond)$ concentration profiles for SSmedium (A) and cheese whey permeate (B) in shake-flask culture. 
more pronounced lag phase is observed for CWP. After the lag phase, the consumption and ethanol production rates are higher for CCWP medium. This is probably due to the medium composition difference that might be richer in the case of CWP (SSlactose medium has just $1 \mathrm{gL}^{-1}$ yeast extract). In less than 30 hours total lactose consumption in CWP was achieved. Moreover, the percentage of theoretical conversion obtained with CWP was comparable with the one obtained with semisynthetic medium (80\% of the theoretical value). These data support the feasibility of using CWP as substrate for alcoholic fermentation without addition of any nutrient. This is important because additional nutrients can hinder economic feasibility in industrial applications.

In Figure 3 the different fermentation parameters measured during pseudo-stationary-state operation of the continuous bioreactor using cheese whey permeate (CWP) at increasing dilution rates are represented. The operation with CWP was initialized at $0.1 \mathrm{~h}^{-1}$ dilution rate after reaching pseudo-stationary state with semisynthetic medium. Each time a residual lactose concentration $\left(<1 \mathrm{gL}^{-1}\right)$ was obtained, the dilution rate was increased stepwise (up to 0.55 $\mathrm{h}^{-1}$ ). Pseudo-stationary state values are the values obtained for each dilution rate, after feeding the bioreactor for five residence times at the same dilution rate or when residual lactose concentration is attained.

The cell concentration inside the bioreactor increased up to $0.36 \mathrm{~h}^{-1}$ dilution rate $(D)$, reaching the maximum value of $42 \mathrm{gL}^{-1}$ (dry weight), which is 10 times higher than the one obtained for shake-flask culture. For $D$ above $0.45 \mathrm{~h}^{-1}$ the cell concentration inside the bioreactor slightly decreased and increased in the effluent. When increasing the dilution rate from $0.45 \mathrm{~h}^{-1}$ to $0.5 \mathrm{~h}^{-1}$, the residual $\left(<1 \mathrm{gL}^{-1}\right)$ lactose

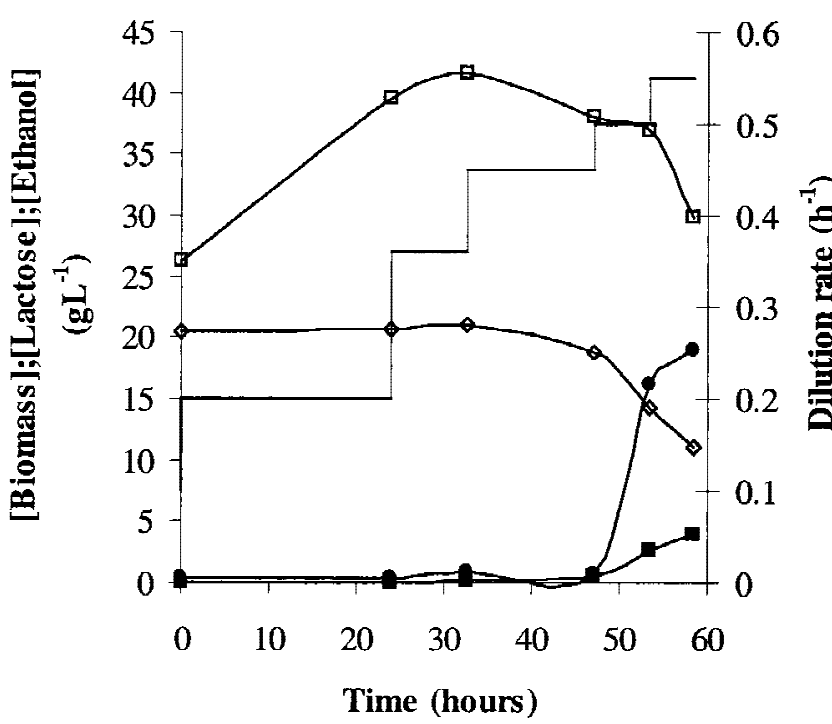

Figure 3. Continuous fermentation time course of: lactose concentration $(\bigcirc)$; ethanol concentration $(\diamond)$; cell concentration in the bioreactor $(\square)$ and in the effluent ( $\square$ ); at pseudo-stationary state with increasing dilution rates (-) for the recombinant $S$. cerevisiae NCYC869-A3/T1, using unsupplemented cheese whey permeate (CWP) as substrate. concentration inside the bioreactor raised to $16 \mathrm{gL}^{-1}$, indicating that $0.45 \mathrm{~h}^{-1}$ was the limiting dilution rate for total lactose consumption. $\mathrm{Up}$ to $0.45 \mathrm{~h}^{-1}$ dilution rate the ethanol concentration was constant, decreasing with the increase of residual lactose concentration. During all the period of operation with CWP the cell viability was above $90 \%$.

Considering that at a given dilution rate, when residual concentration of lactose is achieved, a pseudo-stationary state has been reached, the specific lactose consumption rate and the specific ethanol production rate can be calculated and compared with the ones previously obtained (Domingues et al., 1999b) with semisynthetic medium. The results obtained with CWP overlapped the ones previously obtained with SSlactose medium (Domingues et al., 1999b) confirming not only that the metabolic state of viable cells in the flocs was kept constant at the dilution rates and operational conditions studied, but also that unsupplemented cheese whey ultrafiltrate is an adequate substrate for ethanol fermentation.

This is also confirmed by analysing two other parameters of major importance, that are the \% theoretical conversion $(\eta)$, expressed as

$$
\eta(\%)=\frac{P}{\left(S_{f}-S\right) 0.538} 100
$$

and the ethanol productivity, defined as

$$
Q_{p}=D P
$$

In Figure 4, the ethanol productivity, residual lactose concentration, and \% theoretical conversion for different dilution rates are presented and compared to the values previously obtained with SSlactose medium (Domingues et al., 1999b).

As can be observed, the two systems exhibit similar

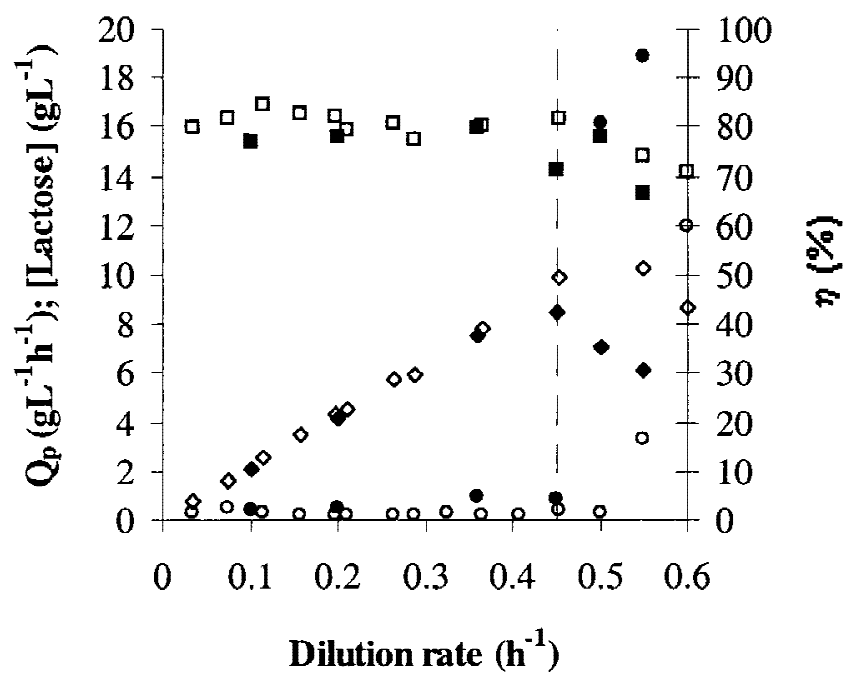

Figure 4. Variation of ethanol productivity $(\diamond, \diamond)$, lactose concentration $(\bigcirc, \bigcirc)$ inside the bioreactor and \% theoretical conversion $(\square, \square)$ with the dilution rate; open symbols for the bioreactor fed with SSlactose medium, closed symbols for the bioreactor fed with cheese whey permeate. 
trends. Both systems have similar ethanol productivity at dilution rates up to $0.45 \mathrm{~h}^{-1}$, after which the system fed with semisynthetic medium exhibits higher productivity. As already observed, this is mainly due to the higher wash-out dilution rate allowed for the bioreactor fed with semisynthetic medium. The wash out at a smaller dilution rate for CWP feed is caused by a slight deflocculation of the yeast strain. This is probably caused by the same factor that leads to deflocculation on the experiments with CCWP, further reported. In a previous study (Domingues et al., 1999b) it has been pointed out how unstable this system becomes when working at dilution rates above $0.45 \mathrm{~h}^{-1}$ and that it would be better to work at $0.45 \mathrm{~h}^{-1}$ even with loss of productivity than working at higher dilution rates. To prove that this difference was not caused by any kind of contamination, a screening for contaminations (twice a day) was done while operating with cheese whey permeate, as it was not sterilized. Bacterial contamination is easily noticed under microscopic observation, while yeast contamination is much more difficult to detect. Because flocculating yeast cells are used, the appearance of a strong turbidity in the culture medium would give a good indication of contamination. However, this is not straightforward because contaminant nonflocculent cells could also interact with the flocculent ones (Soares et al., 1992), and the flocculent cells could also for some reason deflocculate. As such, a screening for yeast contaminants was done with lysine differential medium during the operation and no contaminant was found, confirming the microbiological stability of these systems (Domingues et al., 2000).

As there are several profitable uses for proteins available from cheese whey, either by incorporation of the proteins into cheese products or by recovery and fractionation of these proteins, the permeate has theoretically little or no value (Moulin and Galzy, 1984). However, the volumes produced are so large that some treatment at least is necessary before their disposal as effluent. The proposed fermentation procedure, coupled with protein recovery, enables a reduction higher than $90 \%$ of whey chemical oxygen demand (see Table I). Moreover, the use of the fermentation procedure described herein allows for the attainment of these objectives at a lower cost than existing procedures (Maiorella and Castillo, 1984; Shama, 1988).

As lactose is present in the permeate at a relatively low

Table I. Physicochemical characterization of cheese whey and of the final effluent (obtained after permeate alcoholic fermentation and distillation) ${ }^{\mathrm{a}}$

\begin{tabular}{lccc}
\hline \multicolumn{1}{c}{ Parameter } & Cheese whey & Final effluent & Reduction (\%) \\
\hline $\mathrm{pH}$ & $5.5-6.5$ & $3.8-4.3$ & - \\
$\mathrm{COD}\left(\mathrm{mg}_{\mathrm{O}_{2}} \mathrm{~L}^{-1}\right)$ & 76076 & 7221 & 91 \\
$\mathrm{BOD}_{5}\left(\mathrm{mg}_{\mathrm{O}_{2}} \mathrm{~L}^{-1}\right)$ & 67067 & 2133 & 97 \\
$\mathrm{TSS}\left(\mathrm{mg} \mathrm{L}^{-1}\right)$ & 11440 & 262 & 98 \\
Total nitrogen $\left(\mathrm{mg} \mathrm{L}^{-1}\right)$ & 1329 & 705 & 47
\end{tabular}

${ }^{\mathrm{a}} \mathrm{COD}-\mathrm{Chemical}$ oxygen demand; $\mathrm{BOD}_{5}$ - Biochemical oxygen demand; TSS-Total suspended solids. concentration, its concentration before fermentation can be used to optimize the economics of ethanol recovery by distillation. If the cheese whey permeate (CWP) is concentrated 2 times a fermentation product with $5 \%(\mathrm{w} / \mathrm{v})$ ethanol can be expected. This possibility was also studied, concentrating the permeate with a 150-300 Da cut-off nanofiltration membrane. In Figure 5, the results for batch fermentation of 2 times concentrated cheese whey permeate (CCWP) are shown. This fermentation was performed in a $2-\mathrm{L}$ bioreactor with $\mathrm{pH}$ (set-point 4.0) and temperature (set-point $30^{\circ} \mathrm{C}$ ) control, under $150-\mathrm{rpm}$ agitation. In $30 \mathrm{~h}$ all the lactose (100 $\left.\mathrm{gL}^{-1}\right)$ was metabolized, resulting in $53 \mathrm{gL}^{-1}$ ethanol, clearly indicating that lactose is converted to ethanol with a conversion yield close to the expected theoretical value. It also indicates that the specific growth rate and ethanol specific production rate are not affected by the use of a high initial lactose concentration.

Taking this into account, continuous experiments were done with a $100 \mathrm{gL}^{-1}$ lactose concentration in the feed medium. The first set of experiments was done with SSmedium (100 $\mathrm{gL}^{-1}$ lactose), with the dependence of ethanol productivity on dilution rate presented in Figure 6.

The maximum ethanol productivity is close to the one previously obtained with $50 \mathrm{gL}^{-1}$ (Domingues et al., 1999 b), but is now obtained at a lower dilution rate $(D=$; $\left.0.23 \mathrm{~h}^{-1}\right)$. However, when fed with concentrated cheese whey permeate (CCWP) flocculation was strongly impacted, and it became impossible to reach the abovementioned dilution rate as deflocculated biomass was washed-out from the bioreactor, even when operating at such a low dilution rate as $0.077 \mathrm{~h}^{-1}$. In Figure 7 the main results obtained with the continuous operation of the bioreactor fed with CCWP are summarized.

As can be observed from Figure 7, after $120 \mathrm{~h}$ of continuous operation with 2-times concentrated cheese whey permeate (CCWP), the system could not reach any pseudostationary state as biomass was continuously washed-out from the bioreactor. The increase of biomass concentration

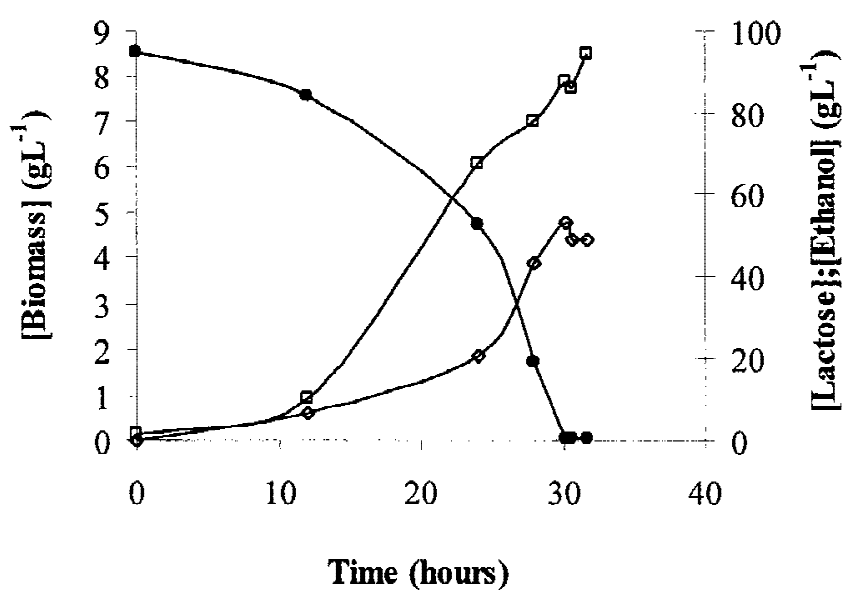

Figure 5. Cell $(\square)$, lactose $(\bullet)$ and ethanol $(\diamond)$ concentration profiles for two times concentrated whey permeate (CCWP) in batch culture. 


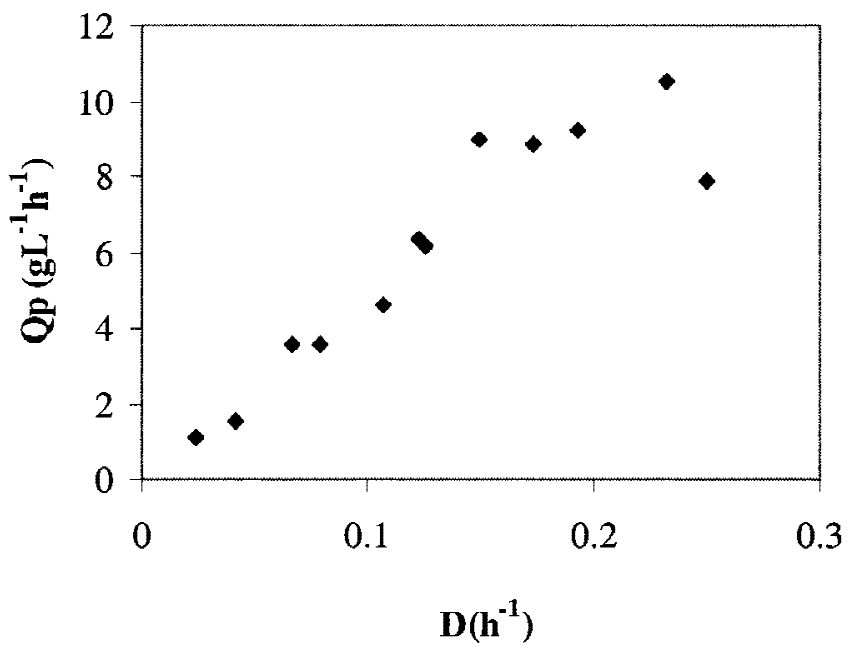

Figure 6. Variation of ethanol productivity with the dilution rate for the bioreactor fed with $100 \mathrm{gL}^{-1}$ lactose semisynthetic medium.

in the outlet was coincident with the decrease of flocculation ability as shown in Figure 8.

The decrease in the flocculation ability may be due to the concentration of salts present in the concentrated cheese whey permeate. An attempt to restore flocculation was made by adding calcium chloride, to a final concentration of $100 \mathrm{mM}$, to the CCWP at $190 \mathrm{~h}$ of continuous operation. Although a slight improvement was noticed both in the bioreactor performance as well as in the flocculation ability, it was far from being satisfactory.

The effect of cation concentration in flocculation is very well documented in the literature (Kihn et al., 1988; Kuriyama et al., 1991; Nishihara, 1982; Stratford, 1989; Stratford and Brundish, 1990; Taylor and Orton, 1973). It is generally accepted that at low concentration, ions promote flocculation while at high concentration they show an inhibitory effect. Sodium ions inhibit flocculation by compe-

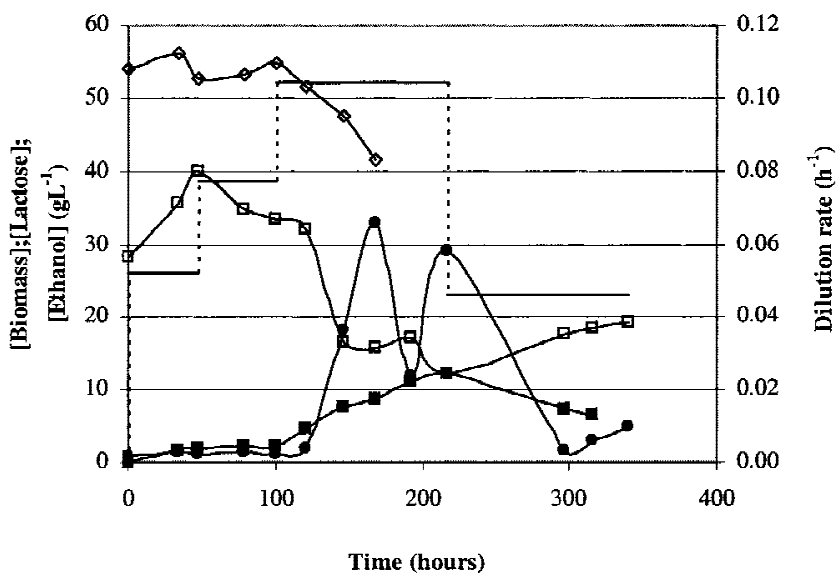

Figure 7. Continuous fermentation time course: lactose concentration $(\bigcirc)$; ethanol concentration $(\diamond)$; cell concentration in the bioreactor $(\square)$ and in the effluent ( $\square$ ); with increasing dilution rates (-) for the recombinant $S$. cerevisiae NCYC869-A3/T1, using two times concentrated cheese whey permeate (CCWP) as substrate.

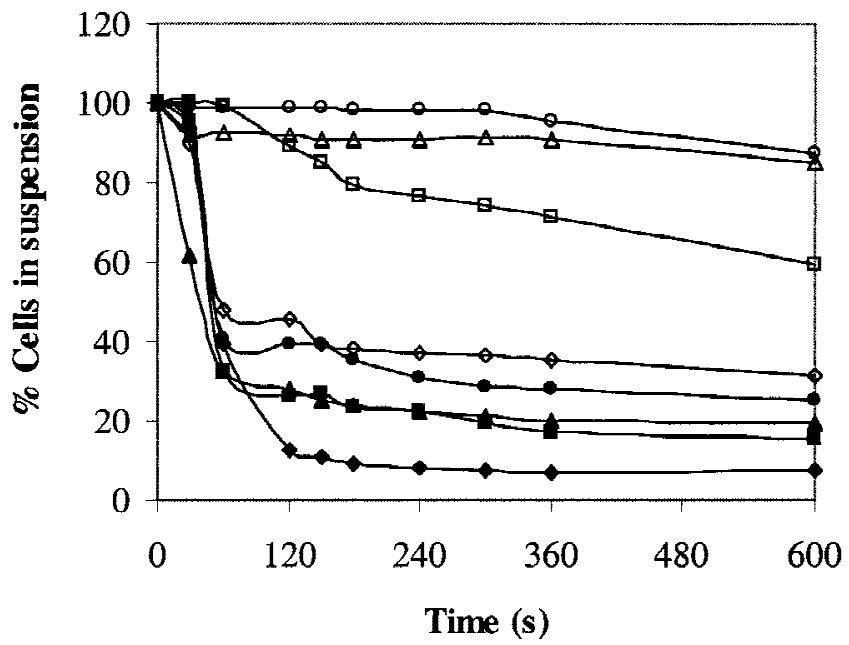

Figure 8. Sedimentation profiles of bioreactor cultured cells during operation with two times concentrated cheese whey permeate (CCWP): Continuous operation with semi-synthetic medium before feeding with CCWP $(\triangleleft)$; Batch operation with CCWP $(\square)$; Beginning of continuous operation, $t=0 \mathrm{~h}(\boldsymbol{\Delta}) ; t=35 \mathrm{~h}(\boldsymbol{\bigcirc}) ; t=48 \mathrm{~h}(\diamond) ; t=78 \mathrm{~h}(\square) ; t=147 \mathrm{~h}(\triangle)$; $t=170 \mathrm{~h}$ of continuous operation $(\bigcirc)$.

tition with calcium ions for specific sites. Potassium and lithium ions are less potent inhibitors than sodium ions (Stratford, 1989). The concentration at which the inhibition occurs is highly strain dependent. Some authors note that at a concentration above $100 \mathrm{~m} M$ flocculation inhibition can be expected (Nishihara, 1982; Taylor and Orton, 1973) while others refer to a lower inhibition concentration (Kihn et al., 1988; Stratford, 1989) or a higher one (Kuriyama et al., 1991). Kihn and co-authors (1988) have tested the effect of cations on flocculation by the yeast strain $S$. cerevisiae NCYC869 (parental wild strain of the transformant T1 presented in this work). For this strain, sodium inhibits flocculation at concentrations from 10 to $100 \mathrm{~m} M$ while lithium and potassium did not inhibit flocculation below $200 \mathrm{~m} M$. The sodium concentration present in the concentrated permeate is $20 \mathrm{mM}$, consistent with partial flocculation inhibition. The potassium concentration in concentrated permeate is $55 \mathrm{mM}$, which is below the inhibition flocculation concentration. However, Stratford and Brundish (1990) found that the inhibition caused by different salts are additive in their effects as noninhibitory concentrations of salts in combination caused inhibition of flocculation. Salts of potassium, which alone were noninhibitory, were found to be good inhibitors of flocculation in combination with other salts. Another important aspect pointed out by these authors was that inhibition by salts is time-dependent; prolonged incubation increased the degree of inhibition. Moreover, near-inhibitory salt concentrations were found to become inhibitory with prolonged incubation. This agrees with the results presented herewith, where the prolonged operation with concentrated whey permeate (CCWP) decreased the cell flocculation capacity. In summary, the concentration of salts present in CCWP affects the flocculation of yeast cells and does not allow for continuous operation at high cell 
density with CCWP. If the salts are removed from the CCWP, it would be possible to attain at least the same productivity as with nonconcentrated whey permeate, but with a higher alcohol content in the end of the fermentation process.

\section{CONCLUSIONS}

Batch experiments showed that the recombinant $S$. cerevisiae strain used in this work was capable of utilizing cheese whey permeate as a carbon and energy source, fermenting $50 \mathrm{gL}^{-1}$ or $100 \mathrm{gL}^{-1}$ of lactose present in cheese whey permeate without any additional nutrient supply.

The continuous-airlift bioreactor, employing this flocculent yeast, is able to ferment lactose present in cheese whey permeate (CWP) to ethanol at a dilution rate of $0.45 \mathrm{~h}^{-1}$. While producing ethanol, the recombinant $S$. cerevisiae strain cleared the cheese whey permeate of most organic substances, allowing for a significant reduction in the pollutant load of the cheese whey. For this system, ethanol productivity near $10 \mathrm{~g} \mathrm{~L}^{-1} \mathrm{~h}^{-1}$ with a bioconversion yield as high as $80 \%$ of the theoretical value and total lactose consumption was obtained. Ethanol productivity is largely superior to that reached with conventional methods (Lyons and Cunningham, 1980). For the continuous operation with 2 times concentrated cheese whey permeate (CCWP), inhibition of cell flocculation by salts was noticed, which hindered the operation at high cell density. If salts are removed, at least the same productivity as for the system fed with whey permeate can be expected, as confirmed by the data obtained with the continuous bioreactor fed with $100 \mathrm{gL}^{-1}$ semisynthetic medium. Moreover, a 5\% ethanol product is obtained, as shown for batch fermentation, minimizing the distillation costs.

Lucília Domingues was supported by a grant PRAXIS XXI/BD/ 11306/97 from Fundação para a Ciência e Tecnologia, Portugal.

\section{NOMENCLATURE}

$P$ ethanol concentration

$S$ lactose concentration

Subscripts

$f$ feed concentration

\section{References}

Barry JA. 1982. Alcohol production from cheese whey. Dairy Ind Int 47:19-22.

Clesceri LS, Greenberg AE, Trussell RR. 1989. Standard methods for the examination of water and wastewater. Washington: American Public Health Association.

Compagno C, Tura A, Ranzi BM, Martegani E. 1993. Bioconversion of lactose/whey to fructose diphosphate with recombinant Saccharomyces cerevisiae cells. Biotechnol Bioeng 42:398-400.
Compagno C, Porro D, Smeraldi C, Ranzi BM. 1995. Fermentation of whey and starch by transformed Saccharomyces cerevisiae cells. Appl Microbiol Biotechnol 43:822-825.

Domingues L, Lima N, Teixeira JA. 2000. Contamination of high cell density bioreactors. Biotechnol Bioeng 68:584-587.

Domingues L, Teixeira JA, Lima N. 1999a. Construction of a flocculent Saccharomyces cerevisiae fermenting lactose. Appl Microbiol Biotechnol 51:621-626.

Domingues L, Dantas MM, Lima N, Teixeira JA. 1999b. Continuous ethanol fermentation of lactose by a recombinant flocculating Saccharomyces cerevisiae strain. Biotechnol Bioeng 64:692-697.

Farahnak F, Seki T, Ryu DY, Ogrydziak D. 1986. Construction of lactoseassimilating and high ethanol producing yeasts by protoplast fusion. Appl Environ Microbiol 51:362-367.

Feijoo G, Moreira MT, Roca E, Lema JM. 1999. Use of cheese whey as a substrate to produce manganese peroxidase by Bjerkandera sp BOS55. J Ind Microbiol 23:86-90.

Gawel J, Kosikowski FV. 1978. Improving alcohol fermentation in concentrated ultrafiltration permeates of cottage cheese whey. J Food Sci 43:1717-1719.

Guimaraes WV, Dudey GL, Ingram LO. 1992. Fermentation of sweet whey by ethanologenic Escherichia coli. Biotechnol Bioeng 40:41-45.

Hahn-Hägerdal B. 1985. Comparison between immobilized Kluyveromyces fragilis and Saccharomyces cerevisiae coimmobilised with $\beta$-galactosidase, with respect to continuous ethanol production from concentrated whey permeate. Biotechnol Bioeng 27:914-916.

Horton B. 1996. Wheys of recovery. Whey Processing May:39-40.

Janssens JH, Bernard A, Bailey RB. 1984. Ethanol from whey: Continuous fermentation with cell recycle. Biotechnol Bioeng 26:1-5.

Kihn JC, Masy CL, Mestdagh MM. 1988. Yeast flocculation: Competition between nonspecific repulsion and specific bonding in cell adhesion. Can J Microbiol 34:773-778.

Kumar V, Ramakrishnan S, Teeri TT, Knowles JKC, Hartley BS. 1992. Saccharomyces cerevisiae cells secreting an Aspergillus niger $\beta$-galactosidase grown on whey permeate. Bio/Technol 10:82-85.

Kuriyama H, Umeda I, Kobayashi H. 1991. Role of cations in the flocculation of Saccharomyces cerevisiae and discrimination of the corresponding proteins. Can J Microbiol 37:397-403.

Lyons TP, Cunningham JD. 1980. Fuel alcohol from whey. Am Dairy Rev 42:42A-42E

Maiorella BL, Castillo FJ. 1984. Ethanol, biomass, and enzyme production for whey waste abatement. Process Biochem 19:157-161.

Mann EJ. 1980. Alcohols from whey. Dairy Ind Int 3:47-48.

Maullu C, Lampis G, Basile T, Infianni A, Rossolini GM, Pompei R. 1999. Production of lysozyme-enriched biomass from cheese industry byproducts. J Appl Microbiol 86:182-186.

Mawson AJ. 1987. Ethanol production from whey in New Zealand. Aust J Biotechnol 1:64-73.

Mehaia MA, Cheryan M. 1986. Lactic acid from acid whey permeate in a membrane recycle bioreactor. Enzyme Microb Technol 8:289-292.

Michel A, Jacob F, Perrier J, Poncet S. 1987. Yeast production from crude sweet whey. Biotechnol Bioeng 30:780-783.

Miller GL. 1959. Use of dinitrosalicylic acid reagent for determination of reducing sugar. Anal Chem 31:426-428.

Moulin G, Guillaume M, Galzy P. 1980. Alcohol production by yeast in ultrafiltrate. Biotechnol Bioeng 32:1277-1281.

Moulin G, Galzy P. 1984. Whey, a potential substrate for biotechnology. Biotechnol Genet Eng Rev 1:347-373.

Nishihara H. 1982. Flocculation of cell walls of brewer's yeast and effects of metal ions, protein-denaturants and enzyme treatments. Arch Microbiol 131:112-115.

Porro D, Martegani E, Ranzi BM, Alberghina L. 1992. Lactose/whey utilization and ethanol production by transformed Saccharomyces cerevisiae cells. Biotechnol Bioeng 39:799-805.

Prenosil JE, Stuker E, Bourne JR. 1987. Formation of oligosaccharides during enzymatic lactose hydrolysis and their importance in a whey hydrolysis process: Part II: Experimental. Biotechnol Bioeng 30: 1026-1031. 
Ramakrishnan S, Hartley BS. 1993. Fermentation of lactose by yeast cells secreting recombinant fungal lactase. Appl Environ Microbiol 59: 4230-4235.

Rech R, Cassini CF, Secchi A, Ayub MAS. 1999. Utilization of proteinhydrolyzed cheese whey for production of $\beta$-galactosidase by Kluyveromyces marxianus. J Ind Microbiol Biotechnol 23:91-96.

Rubio-Teixeira M, Castrillo JI, Adam AC, Ugalde UO, Polaina J. 1998. Highly efficient assimilation of lactose by a metabolically engineered strain of Saccharomyces cerevisiae. Yeast 14:827-837.

Shama G. 1988. Developments in bioreactors for fuel ethanol production. Proc Biochem October:138-145.

Soares EV, Teixeira JA, Mota M. 1992. Interaction between flocculent and nonflocculent cells of Saccharomyces cerevisiae. Can J Microbiol 38 969-974.

Sonawat HM, Agrawal A, Dutta SM. 1981. Production of $\beta$-galactosidase from Kluyveromyces fragilis grown on whey. Folia Microbiol 26 : 370-376.

Sreekrishna K, Dickson RC. 1985. Construction of strains of Saccharomyces cerevisiae that grow on lactose. Proc Natl Acad Sci USA 82: 7909-7913.
Stratford M. 1989. Yeast flocculation: Calcium specificity. Yeast 5: 487-496.

Stratford M, Brundish HM. 1990. Yeast flocculation: Cationic inhibition. Yeast 6:77-86.

Tahoun MK, El-Merheb Z, Salam A, Youssef A. 1987. Biomass and lipids from lactose or whey by Trichosporon beigelii. Biotechnol Bioeng 29:356-360.

Taylor NW, Orton WL. 1973. Effect of alkaline-earth metal salts on flocculence in Saccharomyces cerevisiae. J Inst Brew 79:294-297.

Teixeira JA, Mota M, Goma G. 1990. Continuous ethanol production by a flocculating strain of Kluyveromyces marxianus: bioreactor performance. Bioproc Eng 5:123-127.

Terrel SL, Bernard A, Bailey RB. 1984. Ethanol from whey: Continuous fermentation with a catabolite repression-resistant Saccharomyces cerevisiae mutant. Appl Environ Microbiol 48:577-580.

Tretiak KA, Zakal'skii AE, Gudz' SP. 1998. The cloning and expression of the gene for $\beta$-galactosidase from Candida pseudotropicalis yeasts in Saccharomyces cerevisiae cells. Mikrobiol Z 60:57-66.

Walker J. 1982. Production of fuel grade ethanol from soft drink bottling wastes. Beverage Industry, November:157-160, 163. 